\title{
Catbird and Robin Construct the Same Nest
}

by Maurice G. Street, Nipawin, Sask.

On the morning of June 7, 1959, while working in my garden, I saw a Catbird carrying assorted nesting material including several scraps of paper and other rubbish into a large Red Elderberry bush within a few feet of a path at one side of the garden. The elderberry was in full blossom but only partially in leaf, and the movements of the Catbird could at times be quite clearly seen. A glance or two into the elderberry as I casually walked by on the path showed the nest to be in several closely growing forks about $3 \frac{1}{2}$ feet above the ground, and the nest was at this time but a handful of material. Later in the same day, I watched the nest-site from a distance of about 50 feet for over 30 minutes. During this time the Catbird made six trips with material. Another casual glance now showed the base of the nest to be nearly three inches thick.

Shortly before 7:00 a.m. the following morning the Catbird was again observed to be busily engaged in building. At noon as I walked up the path, I noticed a Robin with its beak full of weed stalks fly into the elderberry. This I thought to be purely accidental, as when I passed the nest-site the Robin flew from the farther side. At 6:45 a.m. the following morning (June 9) the the Robin was again seen carrying

TOWNSEND'S SOLITAIRE NEAR BALDY LAKE, SASK.-On June 25, 1959 , a strange bird was observed near Baldy Lake south of Little Bear Lake along the Hanson Lake road by Chief Ecologist Nelson and Ecologists Maliepaard and Kuyt. The bird was almost the size of a Robin but a little slimmer and with a longer tail. The coloration of the bird was a non-descript gray (darker above) with conspicuous white areas on the outside of the tail and lightcoloured patches on the wings. These patches and the white areas in the tail were especially noticeable while the bird was in flight or when it hopped about on a bulldozed pile of trees and stumps, apparently in search of food. An interesting feature was the bird's habit of flicking its tail on occasion, in the manner of a Waterppipit or European Wagtail, only not nearly as frequently nesting material into the elderberry. Now, being quite puzzled after seeing the Robin leave the bush minus whatever it had carried, I decided to spend a few moments watching, and to my great surprise I watched the Catbird make three trips and the Robin seven trips to the same nest before I had to leave at 7:30 a.m. A close-up inspection of the nest showed the bottom and walls of the nest almost completed. At noon, with only a few minutes to watch, I saw the Robin twice carry beakfuls of mud to the nest. The Catbird was observed in the near vicinity, but was not seen to go near the nest. Late the same evening neither the Robin nor the Catbird was observed to visit the nest in over an hour's watch.

At 7:00 a.m. June 10 , the Robin was sitting on the nest and when it was flushed from it the nest was seen to contain one Robin's egg. A few moments later the Catbird was observed carrying material to another elderberry on the opposite side of the garden, approximately 50 feet away. The next day this new Catbird nest was over half completed, about four feet above the ground. At no time during the period when both the Catbird and Robin were building the same nest was any other than normal behaviour observed on the part of either species.

and executed with a more or less spasmodic jerk which clearly showed the white areas in the tail feathers.

The bird was tentavely identified as a Townsend's Solitaire (Myadestes townsendi). Two of us had not seen this bird before; I was better acquainted with the Solitaire, having observed it on several occasions in in the mountains near the Salmon River, north of Campbell River, Vancouver Island. I had not, however, observed this little-known bird's habit of bobbing its tail.

We have been wondering whether the Solitaire has often been reported from our northern forested regions. I was rather surprised to see it, believing the bird to be confined to the mountains and ranges of B.C., Alberta, Yukon Territory and the western U.S. and Alaska.-E. Kuyt, Hudson Bay, Sask. 